\title{
Penggunaan Tanda Baca Koma (,) dalam Tajuk Rencana pada Siswa di Sekolah Menengah Atas
}

\section{The Use of Comma Punctuation (,) in Editorials in High School Students}

\section{Supriyadin $^{1}$}

Artikel diterima editor tanggal 27-02-2021, disetujui untuk dipublikasikan tanggal 27-05-2021

Doi: $x x x x x-x x x x x$

\begin{abstract}
Abstrak
Tujuan penelitian ini yaitu: (1) Mendapatkan data mengenai kemampuan siswa Kelas XI SMAN 1 Cikijing dalam menggunakan tanda baca koma (,) pada tajuk rencana. (2) Mendapatkan data mengenai kesalahan menggunakan tanda baca koma (,) dalam tajuk. Hipotesis yang diajukan dalam penelitian ini adalah Analisis Kesalahan Penggunaan Tanda Baca Koma (,) dalam Tajuk Rencana pada Siswa Kelas XI SMA Negeri 1 Cikijing. Maka dalam penelitian ini penulis merumuskan hipotesis yaitu: "Masih terdapat kesalahan menggunakan tanda baca koma (,) dalam tajuk rencana pada siswa kelas XI SMA Negeri 1 Cikijing". Penelitian ini menggunakan metode deskriptif kuantitatif. Peneliti melakukan tiga langkah persiapan, yaitu mengumpulkan angket siswa, melakukan analisis penggunaan tanda baca koma (,) tiap teks tajuk rencana dan membuat catatan kesalahan penggunaan tanda baca koma (,). Siswa kelas XI IPS 2 SMAN 1 Cikijing tahun ajar 2014/2015 secara umum telah memiliki kemampuan menggunakan tanda baca koma (,) dalam tajuk rencana. Namun, masih ada beberapa orang yang belum mampu sepenuhnya menggunakan tanda baca koma (,) sesuai dengan kaidah. Kemampuan siswa memahami penggunaan tanda baca koma (,) yang tinggi, dapat dipastikan siswa telah memahami aturan penggunaan tanda baca koma (,) sesuai dengan ejaan yang disempurnakan. Sedangkan kemampuan siswa yang rendah, dapat dipastikan siswa belum memahami penggunaan tanda baca koma (,) sesuai dengan ejaan yang disempurnakan. Masih terdapat kesalahan-kesalahan penggunaan tanda baca koma (,) dalam tajuk rencana yang dilakukan oleh siswa Kelas XI IPS 2 SMAN 1 Cikijing sebesar 22\%, dengan demikian hipotesis penelitian dapat diterima.
\end{abstract}

Kata kunci: kesalahan, tanda koma, tajuk rencana

\begin{abstract}
The objectives of this study were: (1) Obtaining data regarding the ability of Class XI students of SMAN 1 Cikijing in using punctuation marks (,) in the editorial. (2) Obtain data regarding errors using a comma (,) in the header. The hypothesis proposed in this study is the Analysis of Misuse of Comma (.) Punctuation in the Editorial for Class XI Students of SMA Negeri 1 Cikijing for the 2014/2015 academic year. So in this study, the authors formulated a hypothesis, namely: "There is still an error
\end{abstract}

${ }^{1}$ Supriyadin, SMK PGRI Karangampel, supriyadin29@gmail.com 
using a comma (,) punctuation mark in the editorial in class XI SMA Negeri 1 Cikijing". This research uses a descriptive quantitative method. The researcher carried out three preparatory steps, namely collecting student questionnaires, analyzing the use of punctuation marks (,) for each editorial text, and making notes on errors in using punctuation marks (,). Class XI IPS 2 students of SMAN 1 Cikijing academic year general has the ability to use a comma (,) punctuation mark in the editorial. However, there are still some people who are not able to fully use the comma (,) punctuation according to the rules. The ability of students to understand the use of comma (,) punctuation is high, it can be ascertained that students have understood the rules of using comma (,) punctuation according to the enhanced spelling. While the students' low abilities, it can be ascertained that students do not understand the use of commas (,) punctuation according to the enhanced spelling. There are still errors in the use of punctuation marks (,) in the editorial done by students of Class XI IPS 2 SMAN 1 Cikijing of 22\%, thus the research hypothesis can be accepted.

Keywords: errors, commas, editorial

\section{Pendahuluan}

Keterampilan berbahasa dari sudut pandang bahasa terbagi menjadi empat keterampilan di antaranya keterampilan menyimak, berbicara, membaca, dan menulis sesuai yang dikemukakan oleh Tarigan (2008). Dari keempat keterampilan berbahasa itu erat sekali berhubungan satu sama lainnya dengan cara yang beraneka ragam. Keempat keterampilan tersebut pada dasarnya merupakan satu kesatuan atau merupakan catur-tunggal. Keterampilan berbahasa, biasanya diperoleh melalui suatu hubungan urutan yang teratur, mula-mula di masa kecil hal yang dipelajari adalah menyimak bahasa kemudian berbicara, setelah itu kita belajar membaca dan menulis. Menyimak dan berbicara dipelajari sebelum memasuki sekolah.

Selanjutnya, setiap keterampilan tersebut berhubungan erat dengan proses-proses yang mendasari bahasa. Bahasa seseorang merupakan cerminan pikirannya, semakin terampil seseorang berbahasa, semakin cerah dan jelas pula jalan pikirannya. Keterampilan berbahasa hanya dapat diperoleh dan dikuasai melalui praktik dan banyak pelatihan. Pada saat ini makin terasa pentingnya fungsi bahasa sebagai alat komunikasi. Kenyataan yang dihadapi saat ini adalah selain ahli-ahli bahasa, semua ahli yang bergerak dalam bidang pengetahuan yang lain semakin memperdalam diri dibidang teori dan praktik bahasa. Semua orang menyadari bahwa interaksi dan segala macam kegiatan dalam masyarakat akan lumpuh tanpa menggunakan bahasa.

Begitu pula melalui bahasa, kebudayaan suatu bangsa dapat dibentuk, dibina dan dikembangkan serta dapat diturunkan kepada generasi-generasi mendatang. Dengan adanya bahasa sebagai alat komunikasi, maka semua yang berada di sekitar manusia: peristiwa-peristiwa, hewanhewan, tumbuh-tumbuhan, hasil karya cipta manusia dan sebagainya, mendapat tanggapan dalam pikiran manusia, disusun dan diutarakan kembali kepada orang-orang lain sebagai bahan komunikasi. Komunikasi melalui bahasa ini memungkinkan tiap orang untuk dapat menyesuaikan dirinya dengan lingkungan fisik dan lingkungan sosialnya. Keraf (2005) memberikan pengertian dua bahasa. Pengertian pertama bahasa sebagai alat komunikasi antara anggota masyarakat berupa simbol bunyi yang dihasilkan oleh alat ucap manusia. Kedua bahasa adalah sistem komunikasi yang mempergunakan simbol-simbol vokal (bunyi ujaran) yang bersifat arbitrer.

Stiawan (2006) menjelaskan bahwa "bahasa dapat didefinisikan sebagai kode yang diterima secara sosial atau sistem konvensional untuk menyampaikan konsep melalui simbol-simbol yang dikehendaki dan kombinasi simbol-simbol yang diatur oleh ketentuan". Berdasarkan pendapat di atas bahwa bahasa dibagi menjadi dua di antaranya bahasa lisan dan bahasa tulis. Bahasa lisan dipergunakan secara langsung atau bertatap muka oleh dua orang atau lebih. Sedangkan bahasa tulis adalah alat komunikasi yang secara tidak langsung, yaitu melalui simbol-simbol lambang bahasa dalam bentuk tulisan. Kuswari (2009) mengungkapkan "menulis merupakan kegiatan yang mengasyikan bahkan menulis bisa disebutkan sebagai kegiatan kreatif yang akan mengantarkan siswa 


\section{JGI: JURNAL GURU INDONESIA}

2021, 1(1), hlm. 1 - 9

https://jurnal.ppjb-sip.org/index.php/igi/index

E-ISSN: XXXX-XXXX | DOI: $\mathrm{xxxxx-Xxxxx}$

menjadi orang yang sukses dibidang karya tulis". Maksud dari pengertian di atas bahwa dengan mempunyai kemampuan menulis dapat membuat sukses apabila mempunyai manfaat untuk dibaca.

Latihan menulis adalah kunci yang paling utama demi mencapai kesuksesan untuk mendapat predikat (mampu menulis dengan baik dan benar). Seseorang hanya dapat membuat tulisan yang baik jika rajin membaca. Karena dalam interaksi antara seorang pembaca dan bacaan terdapat model tulisan yang dijamin atau sebaliknya. Untuk itu, belajar menulis sangatlah penting diterapkan dalam pendidikan sekolah, apalagi ditambah dengan adanya mata pelajaran bahasa Indonesia. Mata pelajaran bahasa Indonesia merupakan mata pelajaran pokok yang harus diajarkan, mulai dari sekolah dasar sampai ke perguruan tinggi. Perbedaan pada tiap jenjang pendidikan terletak pada ruang lingkup pokok pembahasannya. Hal ini disesuaikan atas dasar pertimbangan wawasan dan kebutuhan. Mengingat keterampilan sangat penting, maka keterampilan ini perlu terus ditingkatkan (Yaldi, 2013) .

Kesalahan dalam pembelajaran menulis sering kali terjadi penyimpangan kaidah bahasa Indonesia seperti halnya pada aspek morfologis, sintaksis, dan semantik termasuk kesalahan menggunakan tanda baca khususnya tanda baca koma (,). Kesalahan penggunaan tanda baca koma (,) oleh siswa ini disebabkan beberapa faktor salah satu di antaranya adalah siswa belum memahami benar menggunakan tanda baca koma (,) yang sesuai dengan Ejaan Yang Disempurnakan (EYD). Hal ini disebabkan kurangnya bimbingan dari guru sehingga kesalahan siswa masih terus berlanjut. Kesalahan penggunaan tanda baca koma, akan berdampak pada pembaca akan salah tafsir mengenai isi bacaan atau kalimat, sehingga maksud penulis akan ditafsirkan berbeda oleh pembacanya. Untuk itu, manfaat EYD dalam berbahasa sangat penting terutama untuk bahasa tulis, seperti penggunaan tanda baca khususnya penggunaan tanda baca koma (,). Manfaat tanda baca koma (,) digunakan sebagai jeda dalam membaca. Seperti halnya dinyatakan oleh Zainurrahman (2013) "tanda baca koma digunakan dalam menulis layaknya jeda ketika berbicara".

Berdasarkan pernyataan di atas maka guru bahasa Indonesia sebagai guru yang profesional hendaknya sebelum mengadakan kegiatan pembelajaran, terlebih dahulu melakukan kajian yang mendalam mengenai materi yang akan diajarkan. Oleh sebab itu, materi yang akan disampaikan oleh guru hendaknya jelas dan mudah dipahami oleh peserta didik. Begitupun dengan penulisan tanda baca koma dalam tajuk rencana. Sehingga, peserta didik mengetahui kriteria-kriteria penggunaan tanda baca koma (,) dalam tajuk rencana tersebut.

Berdasarkan hasil observasi di lapangan siswa Kelas XI SMA seharusnya mereka telah mampu menggunakan tanda baca dalam karangan atau tajuk rencana khususnya tanda baca koma (,). Padahal mereka sudah belajar mengenai tanda baca koma (,) sejak masih di SD. Namun, kenyataannya siswa di Kelas XI SMA Negeri 1 Cikijing penggunaan tanda baca khususnya tanda baca koma (,) masih belum sesuai harapan. Dari empat kelas dengan jumlah 88 siswa Kelas XI SMA Negeri 1 Cikijing yang mampu menggunakan tanda baca koma (,) hanya 40\%. Berdasarkan uraian permasalahan tersebut, penulis tuangkan dalam skripsi yang berjudul "Analisis Kesalahan Penggunaan Tanda Baca Koma (,) dalam Tajuk Rencana pada Siswa Kelas XI SMA Negeri 1 Cikijing".

Berdasarkan latar belakang yang telah dipaparkan, maka tujuan penelitian ini yaitu: (1) Mendapatkan data mengenai kemampuan siswa Kelas XI SMAN 1 Cikijing dalam menggunakan tanda baca koma (,) pada tajuk rencana. (2) Mendapatkan data mengenai kesalahan menggunakan tanda baca koma (,) dalam tajuk.

Hipotesis yang diajukan dalam penelitian ini adalah Analisis Kesalahan Penggunaan Tanda Baca Koma (,) dalam Tajuk Rencana pada Siswa Kelas XI SMA Negeri 1 Cikijing. Maka dalam penelitian ini penulis merumuskan hipotesis yaitu: "Masih terdapat kesalahan menggunakan tanda baca koma (,) dalam tajuk rencana pada siswa kelas XI SMA Negeri 1 Cikijing". 


\section{Metode penelitian}

Penelitian ini menggunakan metode deskriptif kuantitatif, yaitu penelitian yang bertujuan menjelaskan fenomena yang ada dengan menggunakan angka-angka untuk kemudian menjelaskan karakteristik individu atau kelompok. Penelitian deskriptif kuantitatif menilai sifat dari kondisi yang tampak, dalam hal ini yaitu hasil kerja siswa berupa penulisan tanda baca koma (,) dalam tajuk rencana. Tujuan penelitian deskriptif kuantitatif yaitu untuk menggambarkan karakteristik pengetahuan siswa Kelas XI IPS 2 dalam hal penggunaan tanda baca koma (,) dan mengukur kemampuan siswa dalam menggunakan tanda baca koma (,) pada teks tajuk rencana.

Populasi dalam penelitian ini adalah seluruh siswa Kelas XI SMAN 1 Cikijing tahun ajar 2014/2015. Dengan jumlah siswa 88 dari empat kelas dengan rincian sebagai berikut.

Tabel 1

Populasi Siswa Kelas XI SMAN 1 Cikijing

\begin{tabular}{ccc}
\hline No & \multicolumn{1}{c}{ Kelas } & Jumlah Siswa \\
\hline 1. & XI IPA 1 & 24 siswa \\
2. & XI IPA 2 & 23 siswa \\
3. & XI IPS 1 & 20 siswa \\
4. & XI IPS 2 & 21 siswa \\
& Jumlah & $\mathbf{8 8}$ siswa \\
\hline
\end{tabular}

Mengingat jumlah siswa di kelas XI cukup banyak namun masih dalam satu populasi, maka penulis dalam penelitian ini, penentuan sampel menggunakan sampel random sampling atau sampel acak (Sugiyono, 2014). Hal ini dilakukan karena populasi bersifat homogen, seluruhnya kelas XI. Berdasarkan hasil random ditetapkan siswa kelas XI IPS 2 dengan jumlah 21 siswa sebagai sampel.

Adapun langkah yang penulis tempuh dalam pengumpulan data, yaitu sebagai berikut. Penulis membagikan teks tajuk rencana yang menjadi objek dan bahan penelitian kepada siswa. Tajuk rencana tersebut diberikan setelah dihilangkan tanda baca komanya. Penulis menjelaskan pada siswa untuk menggunakan tanda baca koma (,) pada tajuk rencana tersebut. Siswa mengerjakan tugas dengan cara melengkapi tanda baca koma (,) pada tajuk rencana. Setelah selesai, hasil pekerjaan siswa dikumpulkan. Hasil pekerjaan siswa dianalisis penggunaan tanda baca koma (,) pada tajuk rencana. Penulis menentukan tingkat kemampuan siswa menggunakan tanda baca koma (,) pada tajuk rencana. Penulis menganalisis kesalahan-kesalahan penggunaan tanda baca koma (,) pada tajuk rencana.

Berdasarkan proses penelitian kuantitatif, peneliti melakukan tiga langkah persiapan, yaitu mengumpulkan angket siswa, melakukan analisis penggunaan tanda baca koma (,) tiap teks tajuk rencana dan membuat catatan kesalahan penggunaan tanda baca koma (,). Setelah ketiga langkah awal ini dilakukan, maka penulis mengambil kesimpulan mengenai kesalahan penggunaan tanda baca koma (,) dalam tajuk rencana.

\section{Pembahasan}

Berdasarkan pada tajuk rencana yang sudah dilengkapi oleh siswa Kelas XI IPS 2 SMAN 1 Cikijing, maka berikut data hasil penelitiannya yang telah penulis masukan ke dalam tabel rubrik penilaian data penelitian: 


\section{JGI: JURNAL GURU INDONESIA}

2021, 1(1), hlm. 1 - 9

https://jurnal.ppjb-sip.org/index.php/jgi/index

E-ISSN: XXXX-XXXX | DOI: $\mathrm{xxxxx- \textrm {xxxxx }}$

Tabel 2

Data Penilaian Penggunaan Tanda Baca Koma (,)

\begin{tabular}{cccccc}
\hline No & Nama Siswa & $\begin{array}{c}\text { Banyaknya Tanda } \\
\text { Baca Koma }\end{array}$ & Benar & Salah & $\begin{array}{c}\text { Nilai } \\
\text { Kemampuan }\end{array}$ \\
\hline 1. & Siswa A & 14 & 11 & 3 & 78 \\
2. & Siswa B & 14 & 11 & 3 & 78 \\
3. & Siswa C & 14 & 11 & 3 & 78 \\
4. & Siswa D & 14 & 12 & 2 & 85 \\
5. & Siswa E & 14 & 10 & 4 & 71 \\
6. & Siswa F & 14 & 10 & 4 & 71 \\
7. & Siswa G & 14 & 11 & 3 & 78 \\
8. & Siswa H & 14 & 10 & 4 & 71 \\
9. & Siswa I & 14 & 11 & 3 & 78 \\
10. & Siswa J & 14 & 12 & 2 & 85 \\
11. & Siswa K & 14 & 11 & 3 & 78 \\
12. & Siswa L & 14 & 11 & 3 & 78 \\
13. & Siswa M & 14 & 10 & 4 & 71 \\
14. & Siswa N & 14 & 10 & 4 & 71 \\
15. & Siswa O & 14 & 12 & 2 & 85 \\
16. & Siswa P & - & - & - & - \\
17. & Siswa Q & 14 & 13 & 1 & 92 \\
18. & Siswa R & 14 & 11 & 3 & 78 \\
19. & Siswa S & 14 & 10 & 4 & 71 \\
20. & Siswa T & 14 & 11 & 3 & 78 \\
21. & Siswa U & 14 & 10 & 4 & 71 \\
& Jumlah & 280 & 218 & 62 & 1546 \\
\hline
\end{tabular}

Keterangan :

Jumlah tanda baca koma (,) seluruhnya 280.

Jumlah tanda baca koma (,) yang benar $218=78 \%$

Jumlah tanda baca koma (,) yang salah $62=22 \%$

Nilai rata-rata yang benar $=78$

\section{a. Pembahasan Hasil Penelitian}

Berdasarkan pada tabel 4.1: data penilaian tanda baca koma di atas, maka berikut penjabaran kesalahan dan pembetulan penggunaan tanda baca koma (,) dalam tajuk rencana yang dilakukan oleh siswa kelas XI IPS 2 SMAN 1 Cikijing tahun ajar 2014/2015 sesuai dengan buku Ejaan Yang Disempurnakan.

1) Siswa $A$
a) Ditulis : Bencana alam termasuk banjir
Seharusnya : Bencana alam, termasuk banjir
b) Ditulis : termasuk banjir adalah keniscayaan bagi Indonesia
Seharusnya : termasuk banjir, adalah keniscayaan bagi Indonesia
c) Ditulis : Senin 27 Januari 2014
Seharusnya : Senin, 27 Januari 2014

2) Siswa B
a) Ditulis
: pengaruh luas seperti banjir 

Seharusnya : pengaruh luas, seperti banjir
b) Ditulis : seperti banjir adalah naiknya harga pangan
Seharusnya : seperti banjir, adalah naiknya harga pangan
c) Ditulis : Di luar itu triliunan rupiah
Seharusnya : Di luar itu, triliunan rupiah

3) Siswa C
a) Ditulis
: Bencana alam termasuk banjir
Seharusnya
: Bencana alam, termasuk banjir
b) Ditulis
: termasuk banjir adalah keniscayaan bagi Indonesia
Seharusnya
: termasuk banjir, adalah keniscayaan bagi Indonesia
c) Ditulis
: Di luar itu triliunan rupiah
Seharusnya
: Di luar itu, triliunan rupiah

4) Siswa $D$
a) Ditulis
: sabtu lalu yang merusak banyak bangunan
Seharusnya
: sabtu lalu, yang merusak banyak bangunan
b) Ditulis
: Di luar itu triliunan rupiah
Seharusnya
: Di luar itu, triliunan rupiah

5) Siswa $E$
a) Ditulis Seharusnya
: seperti banjir adalah naiknya harga pangan
b) Ditulis Seharusnya
: seperti banjir, adalah naiknya harga pangan
: di Manado Sulawesi Utara
: di Manado, Sulawesi Utara
c) Ditulis Seharusnya
: sabtu lalu yang merusak banyak bangunan
: sabtu lalu, yang merusak banyak bangunan
d) Ditulis
Seharusnya
: Bencana alam termasuk banjir

6) Siswa $F$
a) Ditulis
: seperti, banjir adalah naiknya harga pangan
Seharusnya
: seperti banjir, adalah naiknya harga pangan
b) Ditulis Seharusnya
: sabtu lalu yang merusak banyak bangunan
c) Ditulis
: sabtu lalu, yang merusak banyak bangunan
Seharusnya
: beriklim tropis basah berada di kawasan gunung berapi
: beriklim tropis basah, berada di kawasan gunung berapi

7) Siswa G
a) Ditulis
:seperti banjir adalah naiknya harga pangan
Seharusnya
: seperti banjir, adalah naiknya harga pangan
b) Ditulis
: sejak awal tahun seperti di Manado
Seharusnya
: sejak awal tahun, seperti di Manado
c) Ditulis
: sabtu lalu yang merusak banyak bangunan
Seharusnya
: sabtu lalu, yang merusak banyak bangunan
d) Ditulis
Seharusnya
: di kawasan gunung berapi dan di antara dua lempeng benua
: di kawasan gunung berapi, dan di antara dua lempeng benua

8) Siswa $\mathrm{H}$
a) Ditulis
: pengaruh luas seperti banjir
Seharusnya
: pengaruh luas, seperti banjir
b) Ditulis
Seharusnya
: seperti banjir adalah naiknya harga pangan
c) Ditulis
: seperti banjir, adalah naiknya harga pangan
: beriklim tropis basah berada di kawasan gunung berapi
d) Ditulis
: beriklim tropis basah, berada di kawasan gunung berapi
: di kawasan gunung berapi dan di antara dua lempeng benua 


\section{JGI: JURNAL GURU INDONESIA}

2021, 1(1), hlm. 1 - 9

https://jurnal.ppjb-sip.org/index.php/jgi/index

E-ISSN: XXXX-XXXX | DOI: $\mathrm{xxxxx-xxxxx}$

Seharusnya : di kawasan gunung berapi, dan di antara dua lempeng benua

9) Siswa I
a) Ditulis
: seperti banjir adalah, naiknya harga pangan
Seharusnya
: seperti banjir, adalah naiknya harga pangan
b) Ditulis
: seperti Manado Sulawesi Utara
Seharusnya
: seperti Manado, Sulawesi Utara

10) Siswa J
a) Ditulis
: termasuk banjir adalah keniscayaan bagi Indonesia
Seharusnya
: termasuk banjir, adalah keniscayaan bagi Indonesia
b) Ditulis
: Di luar itu triliunan rupiah lagi hilang
Seharusnya
: Di luar itu, triliunan rupiah lagi hilang

11) Siswa K
a) Ditulis
: pengaruh luas seperti banjir
Seharusnya
: pengaruh luas, seperti banjir
b) Ditulis
Seharusnya
: seperti banjir adalah naiknya harga pangan
c) Ditulis
Seharusnya
: seperti banjir, adalah naiknya harga pangan
: Di luar itu triliunan rupiah lagi hilang

12) Siswa $L$
a) Ditulis : sejak awal tahun seperti di Manado
Seharusnya : sejak awal tahun, seperti di Manado
b) Ditulis : : sabtu lalu yang merusak banyak bangunan
Seharusnya : sabtu lalu, yang merusak banyak bangunan
c) Ditulis : termasuk banjir adalah keniscayaan bagi Indonesia

13) Siswa $M$
a) Ditulis
: pengaruh luas seperti banjir
Seharusnya
: pengaruh luas, seperti banjir
b) Ditulis
: seperti banjir adalah naiknya harga pangan
c) Ditulis
: seperti banjir, adalah naiknya harga pangan
Seharusnya
: Bencana alam termasuk banjir
d) Ditulis
Seharusnya
: Bencana alam, termasuk banjir
: termasuk banjir adalah keniscayaan bagi Indonesia
: termasuk banjir, adalah keniscayaan bagi Indonesia

14) Siswa N
a) Ditulis
: sabtu lalu yang merusak banyak bangunan
Seharusnya
: sabtu lalu, yang merusak banyak bangunan
b) Ditulis
Seharusnya
: Di luar itu triliunan rupiah lagi hilang
c) Ditulis
: Di luar itu, triliunan rupiah lagi hilang
$\begin{array}{ll}\text { d) Ditulis } & \text { : Senin } 27 \text { Januari } 2014 \\ \text { Seharusnya } & \text { : Senin, } 27 \text { Januari } 2014\end{array}$

15) Siswa 0
a) Ditulis
: seperti banjir adalah naiknya harga pangan
Seharusnya
: seperti banjir, adalah naiknya harga pangan
b) Ditulis
: Di luar itu triliunan rupiah lagi hilang 
16) Siswa $Q$

Seharusnya : Di luar itu, triliunan rupiah lagi hilang
a) Ditulis
: sabtu lalu yang merusak banyak bangunan
b) Seharusnya : sabtu lalu, yang merusak banyak bangunan

17) Siswa $R$
a) Ditulis
: pengaruh luas seperti banjir
Seharusnya : pengaruh luas, seperti banjir
b) Ditulis : sabtu lalu yang merusak banyak bangunan
Seharusnya : sabtu lalu, yang merusak banyak bangunan
c) Ditulis : termasuk banjir adalah keniscayaan bagi Indonesia
Seharusnya : termasuk banjir, adalah keniscayaan bagi Indonesia

18) Siswa $S$
a) Ditulis : pengaruh luas seperti banjir
Seharusnya : pengaruh luas, seperti banjir
b) Ditulis
Seharusnya : seperti di Manado, Sulawesi Utara
c) Ditulis
Seharusnya : seperti banjir, adalah naiknya harga pangan
d) Ditulis : Di luar itu triliunan rupiah lagi hilang
Seharusnya : Di luar itu, triliunan rupiah lagi hilang

19) Siswa $T$
a) Ditulis : pengaruh luas seperti banjir
Seharusnya : pengaruh luas, seperti banjir
b) Ditulis : seperti banjir adalah naiknya harga pangan
Seharusnya : seperti banjir, adalah naiknya harga pangan
$\begin{array}{ll}\text { c) Ditulis } & \text { : Di luar itu triliunan rupiah lagi hilang } \\ \text { Seharusnya } & \text { : Di luar itu, triliunan rupiah lagi hilang }\end{array}$

20) Siswa U
a) Ditulis
b) Ditulis : seperti banjir adalah naiknya harga pangan
Seharusnya : seperti banjir, adalah naiknya harga pangan
c) Ditulis : Sabtu lalu yang merusak banyak bangunan
Seharusnya : Sabtu lalu, yang merusak banyak bangunan
$\begin{array}{ll}\text { d) Ditulis } & \text { : termasuk banjir adalah keniscayaan bagi Indonesia } \\ \text { Seharusnya } & : \text { termasuk banjir, adalah keniscayaan bagi Indonesia }\end{array}$

Berdasarkan hasil analisis dari rubrik penilaian data penelitian penggunaan tanda baca koma (,) dan analisis kesalahan penggunaan tanda baca koma, maka dapat penulis simpulkan dari jumlah tanda baca koma (,) dalam tajuk rencana sebanyak 14 buah, penggunaan yang benar mencapai $78 \%$ dan kesalahan yang dilakukan siswa Kelas XI IPS 2 SMAN 1 Cikijing tahun ajar 2014/2015 dalam penggunaan tanda baca koma (,) dalam tajuk rencana, sebanyak $22 \%$.

Adapun hipotesis yang penulis ajukan sebelumnya yaitu "Masih terdapat kesalahan menggunakan tanda baca koma (,) dalam tajuk rencana pada siswa kelas XI SMA Negeri 1 Cikijing". Hasil uji hipotesis dapat dilihat berdasarkan pada tabel rubrik penilaian data penelitian dan analisis kesalahan penggunaan tanda baca koma (,) dalam tajuk rencana, masih terdapat kesalahan yang dilakukan siswa dalam penggunaan tanda baca koma (,) sebesar $22 \%$. Dengan demikian hipotesis penelitian dapat diterima. 


\section{JGI: JURNAL GURU INDONESIA}

2021, 1(1), hlm. 1 - 9

https://jurnal.ppjb-sip.org/index.php/jgi/index

E-ISSN: XXXX-XXXX | DOI: $\mathrm{xxxxx- \textrm {xxxxx }}$

\section{Simpulan}

Berdasarkan pada rumusan masalah dan hasil penelitian yang telah dilakukan oleh penulis, berikut kesimpulannya: Siswa kelas XI IPS 2 SMAN 1 Cikijing tahun ajar 2014/2015 secara umum telah memiliki kemampuan menggunakan tanda baca koma (,) dalam tajuk rencana. Namun, masih ada beberapa orang yang belum mampu sepenuhnya menggunakan tanda baca koma (,) sesuai dengan kaidah. Kemampuan siswa memahami penggunaan tanda baca koma (,) yang tinggi, dapat dipastikan siswa telah memahami aturan penggunaan tanda baca koma (,) sesuai dengan ejaan yang disempurnakan. Sedangkan kemampuan siswa yang rendah, dapat dipastikan siswa belum memahami penggunaan tanda baca koma (,) sesuai dengan ejaan yang disempurnakan, masih terdapat kesalahan-kesalahan penggunaan tanda baca koma (,) dalam tajuk rencana yang dilakukan oleh siswa Kelas XI IPS 2 SMAN 1 Cikijing tahun ajar 2014/2015 sebesar 22\%.

\section{Daftar pustaka}

Keraf. S. (2005). Kadhipta. Jakarta: Balai Pustaka.

Kuswari, U. (2009). Dasar-Dasar Menulis. Diakses 5 April 2015, dari http://astutiamin.wordpress.com Stiawan, Y. (2006). Perkembangan Bahasa di Postingan dari Situs. Diakses 5 April 2015, dari www.siaksoft.com.

Sugiyono. (2014). Metode Penelitian. Bandung: Alfabeta.

Tarigan, H.G. (2008). Berbicara. Bandung: Angkasa.

Yaldi. (2013). Analisis penggunaan tanda baca titik dan koma pada karangan narasi siswa kelas vii sekolah menengah pertama negeri 9 tanjungpinang tahun ajaran 2012/2013. Repository. Diakses 13 Januari 2021, dari https://jurnal.umrah.ac.id/wp-content/uploads/2013/08/Yaldi090388201353.pdf.

Zainurahman. (2013). Menulis: Dari Teori Hingga Praktik. Bandung: Alfabeta. 